\title{
High-level expression of a recombinant active microbial transglutaminase in Escherichia coli
}

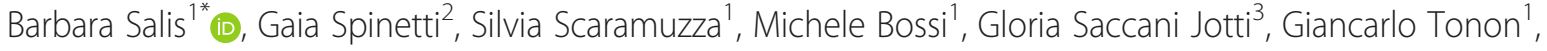 \\ Davide Crobu ${ }^{1}$ and Rodolfo Schrepfer ${ }^{1}$
}

\begin{abstract}
Background: Bacterial transglutaminases are increasingly required as industrial reagents for in vitro modification of proteins in different fields such as in food processing as well as for enzymatic site-specific covalent conjugation of therapeutic proteins to polyethylene glycol to get derivatives with improved clinical performances.

In this work we studied the production in Escherichia coli of a recombinant transglutaminase from Streptomyces mobaraensis (microbial transglutaminase or MTGase) as enzymatically active chimeric forms using different expression systems under the control of both lac promoter or thermoinducible phage lambda promoter.
\end{abstract}

Results: Thermoinducible and constitutive expression vectors were constructed expressing Met-MTGase with chimeric $\mathrm{LacZ}_{1-8} \mathrm{PNP}_{1-20}$ or $\mathrm{LaCZ}_{1-8}$ fusion protein under different promoters. After transformed in competent Escherichia coli K12 strains were fermented in batch and fed-bach mode in different mediums in order to select the best conditions of expression.

The two most performing fusion protein systems namely short thermoinducible LacZ ${ }_{1-8}$ Met-MTGase from NP668/1 and long constitutive $\mathrm{LacZ}_{1-8} \mathrm{PNP}_{1-20}$ Met-MTGase from NP650/1 has been chosen to compare both efficiency of expression and biochemical qualities of the product. Proteins were extracted, purified to homogeneity and verified as a single peak obtained in RP-HPLC. The LacZ $Z_{1-8}$ PNP $_{1-20}$ Met-MTGase fusion protein purified from NP650/1 exhibited an activity of $15 \mathrm{U} / \mathrm{mg}$ compared to $24 \mathrm{U} / \mathrm{mg}$ for the shorter fusion protein purified from NP668/1 cell strain.

Conclusions: Combining the experimental data on expression levels and specific activities of purified MTGase fusion proteins, the chimeric LacZ $Z_{1-8}$ Met-MTGase, which displays an enzymatic activity comparable to the wild-type enzyme, was selected as a candidate for producing microbial transglutaminase for industrial applications.

\section{Background}

Transglutaminases (TGases, protein-glutamine $\gamma$ - glutamyltransferase, E.C.2.3.2.13) are a large family of multifunctional enzymes occurring in several organisms, including mammals, invertebrates, plants and microorganisms. These enzymes catalyze an acyl transfer reaction between the $\gamma$-carboxyamide group of a peptidebound glutaminyl residue (acting as acyl donor) and a variety of primary amines (acting as acceptor) including the $\varepsilon$-amino group of a peptide-bound lysine, resulting in the formation of a new $\gamma$-glutaminyl covalent link and ammonia [1].

\footnotetext{
*Correspondence: barbara.salis@multimedica.it

'Bio-Ker S.r.l., Sardinia Scientific and Technological Park, Building 3, 09010 Pula, Cagliari, Italy

Full list of author information is available at the end of the article
}

It is widely demonstrated that transglutaminase is involved in several physiological process. For instance, it serves a key factor in pancreatic fl-cell during glucosestimulated insulin release through $\mathrm{Ca}^{2+}$ dependent enzyme reaction in isolated islets of Langerhans [2].

Moreover, transglutaminase family is widely expressed in cardiovascular cells and in macrophages, and the recent studies have documented diverse roles for transglutaminases in cardiovascular pathophysiology, in chronic as well as the acute manifestations of atherosclerosis (e.g., plaque rupture). Transglutaminases can modulate several cardiovascular risk factors, especially hypertension [3].

The ability to promote covalent modifications of proteins by intra- and intermolecular linkages catalyzed by tranglutaminases is also exploited in industrial food as an established procedure to improve the texture and the nutritional value of different foods [4]. More recently, 
based on mild operative conditions and the recognition of specific substrate sequences, transglutaminases have been proposed as efficient catalysts for site-specific labeling of proteins with ligand molecules, as for example in the case of enzymatic pegylation of recombinant therapeutic proteins whose pharmacokinetics and/or pharmacodynamic properties can be modulated by covalent binding of high molecular weight poly(ethylene glycol) moieties [5].

Known microbial transglutaminases (MTGase) differ from the mammalian enzymes in that they lack any sequence homology, display $\mathrm{Ca}^{2+}$ independent activity and have smaller molecular masses [6]. Due to their properties, including $\mathrm{Ca}^{2+}$ independent activity, high reaction and broad specificity for acyl donors, microbial transglutaminases are advantageously used in industrial application both in food and in pharmaceutical fields.

A microbial transglutaminase (MTGase) from Streptoverticillium mobaraensis (S.mobarensis) has been isolated, characterized and cloned [7]. This protein, which consists of 331 amino acids with a molecular mass of $37.9 \mathrm{kDa}$, is biosynthesized as a pre-proprotein, then secreted from cytoplasmic compartment as inactive pro-MTGase which is finally activated by proteolytic processing to the enzymatically active mature form [8].

MTGase was first prepared by conventional cultivation of wild-type strain of S.mobaraensis where the secreted inactive pro-enzyme was activated by endogenous proteases [9]. Later on, a number of reports have described the production of MTGase in different recombinant bacterial hosts such as Streptomyces lividans [10, 11], Lactococcus lactis [12] and Escherichia coli [13]. Because of its protein cross linking activity, MTGase is a potentially toxic agent for the recombinant expression hosts if produced intracellularly in an active form. Therefore, the expression as functionally inactive pro-enzyme with subsequent in vitro activation by cleavage of the pro-sequence or, alternatively, the expression of mature MTGase as insoluble inclusion bodies followed by in vitro refolding is necessary.

In a previous work, we found that recombinant proteins bearing an $\mathrm{N}$-terminal extension consisting of a few LacZ residues followed by the first twenty residues of the enzyme purine nucleoside phosphorylase $\left(\mathrm{PNP}_{1-20}\right)$ when expressed in Escherichia.coli (E.coli), were invariably accumulated at high level inside the cell as cytoplasmic inclusion bodies [14]. In the present paper we describe the application of the same fusion protein technology for producing recombinant MTGase in E.coli according to different expression systems comprising a constitutive and thermoinducibile one under the control of the $\lambda$ phage promoter. The results confirmed the critical importance of the N-terminal extension to obtain both high level expression of MTGase and its cytoplasmic segregation in inclusion bodies. Starting from washed inclusion bodies we also developed an efficient refolding and purification protocol to obtain a final MTGase preparation which displayed highly specific activity.

In conclusion, the procedure described in this work could potentially be applied for producing pure recombinant MTGase on a commercial scale for subsequent use as a convenient biocatalyst for the preparation of new protein conjugates.

To date, the mainly bacterial expression system to biosynthesise transglutaminases is (S.mobarensis), this system however has some drawbacks, involving, e.g. problems related to post-translational protein modification [4]. In this work we present a cheaper and more efficient system based on the E.coli peculiarity to highly express recombinant proteins by inclusion body identifying and developing the most performing expression system, the procedure described could therefore potentially be applied for producing pure recombinant MTGase on a commercial scale for subsequent use as a convenient biocatalyst for the preparation of new protein conjugates.

\section{Methods}

\section{General methods}

All DNA manipulations, including restriction digestions, ligations and electrophoresis on agarose gels, were carried out as described [15]. Restriction and DNA-modifying enzymes were purchased from New England Biolabs (Beverly, MA, USA) and used according to the manufacturer's instructions. PCR experiments were performed using a PCR thermal cycler (Gene Amp ${ }^{\circ}$ PCR System 2700, Applied Biosystems), a high fidelity PCR system (PfuTurbo Hot Start and Easy A Hi Fi from Stratagene) and oligonucleotides synthesized by M-Medical (Milan, Italy). Plasmid extractions from agarose gels and PCR purifications were performed using Qiagen kits. The competent cells were transformed using the Bio-Rad E. coli Pulser transformation apparatus and selected using antibiotic resistance.

Soytone, yeast extract and all other chemicals and components for the preparation of culture media were from Merck, Sigma-Aldrich or Fluka.

\section{Synthetic CDNA coding for Met-MTGase}

cDNA coding for mature S.mobaraensis MTGase (GenBank database accession $n^{\circ}$ DQ132977) optimized according to E.coli codon usage was synthesized by Sloning Bio Technology GmbH (Puchheim, Germany) using a proprietary genetic algorithm. Essentially, rare codons were replaced with the most frequently used E.coli codon for each particular amino acid. Other parameters such as GCcontent bias, stability of the RNA secondary structure and length of direct and inverted repeats were also assessed following codon optimisation. 
A starting ATG codon for Met residue at the $\mathrm{N}$-terminus and two consecutive stop codons TAA TGA at C-terminus have been added. The synthetic gene was transferred to the HpaI-XhoI sites of plasmid pPCRScript (from Sloning, Puchheim, Germany) to give the vector PL444 enconding for Met-MTGase.

\section{Construction of thermoinducible vectors}

The thermoinducible expression vectors were constructed starting from plasmid PL420 previously prepared in our laboratory for expressing interferon beta (IFN- $\beta-1 b$ ) as chimeric $\mathrm{LacZ}_{1-8} \mathrm{PNP}_{1-20}$ fusion protein under the $\lambda$ phage promoter, and characterized for the presence of the following main components:

- a 1375 bp fragment comprising the PR and PL promoters and the sequence coding for the thermosensitive repressor cI857 isolated from plasmid pND201 [16]

- a coding sequence for IFN- $\beta$-1b immediately dowstream of a oligonucleotide sequence coding for the first 8 residues of LacZ protein (UniProt/SwissProt Accession No. Q37953) and the first 20 aminoacids of E.coli purine nucleoside phosphorylase [14]

- the kanamycine resistance gene and the pUC19 origin of replication

- a multicloning site.

In vectors containing $\mathrm{PR}$ and $\mathrm{PL}$ promoters of bacteriophage $\lambda$, transcription may be controlled by the $\lambda$ repressor, supplied by expression of $c I$ gene. If a temperature-sensitive allele of $c I$ is used (e.g., cI857), transcription from the strong promoters is repressed in cells growing at $30{ }^{\circ} \mathrm{C}$. At $42{ }^{\circ} \mathrm{C}$, the thermolabile repressor is inactivated and transcription is enabled [16]. In our experiments we noticed that the strong promoter is repressed until $37^{\circ} \mathrm{C}$, therefore we used this temperature for cell growing and $42{ }^{\circ} \mathrm{C}$ for expression of protein.

The sequence coding for Met-MTGase ${ }_{1-332}$ was excised by HpaI-XhoI digestion of PL444 and cloned in the same restriction sites of PL420 to obtain the vector PL447 for the expression of mature Met-MTGase enzyme under the $\lambda$ phage promoter (Fig. 1, panel a).

The sequence coding for Met-MTGase M-332 $_{1-3}$ was PCR amplified from PL455 using the sense primer 5' GTTTAAACGTATGGACAGCGATGACCG 3' (with the PmeI site and the Met-MTGase start codon underlined) and the antisense primer 5'CTCGAGTCATTAT GGCCAGCCTTGTTTAAC 3' (with the XhoI site and the complementary sequence of a double stop codon underlined).

The amplified fragment was cloned in pCRII TOPO (TA Cloning kit, Cat $\mathrm{n}^{\circ}$ K2020-20, Invitrogen) obtaining PL457 and later restricted by HpaI-XhoI and cloned in the same restriction sites of PL420 dowstream of sequence coding for $\mathrm{LacZ}_{1-8} \mathrm{PNP}_{1-20}$ to obtain the vector PL464 for the expression of the chimeric protein $\mathrm{LacZ}_{1-8} \mathrm{PNP}_{1-20^{-}}$ Met-MTGase under the $\lambda$ phage promoter (Fig. 1, panel b).

The vector for expressing $\mathrm{LacZ}_{1-8}$ Met-MTGase was constructed using an intermediate vector. The plasmid, called PL471, was prepared by PCR amplification of PL464 with two oligonucleotides that only excluded the sequence coding for $\mathrm{PNP}_{1-20}$ using the sense primer 5'ATGGACAGCGATGACCGCGTG 3' (where the Met-MTGase start codon is underlined) and the antisense primer

5' GGAAGAATTCGTAATCATGGTCATAGGTTAAC $3^{\prime}$ (where the first underlined codon is the complementary codon for the last aminoacid of $\mathrm{LacZ}_{1-8}$ fragment). Since plasmid PL471 had been amplified by PCR, the region between the HpaI-XhoI restriction sites of PL471 was sequenced and then transferred into PL464 to obtain the final vector for expressing $\mathrm{LacZ}_{1-8}$ Met-MTGase under the $\lambda$ phage promoter denominated PL473 (Fig. 1, panel c).

\section{Construction of constitutive vectors}

The constitutive expression vectors were constructed starting from plasmid PL340 previously prepared in our laboratory for expressing Met-G-CSF as hybrid $\mathrm{LacZ}_{1-8} \mathrm{PNP}_{1-20}$ fusion protein under the lac promoter, and characterized for the presence of the following main components:

- the lac promoter of commercially available pUC18 vector (ATCC N $\mathrm{N}^{\circ} 37253$ )

- a coding sequence for Met-G-CSF immediately dowstream of a oligonucleotide sequence coding for the first 8 residues of LacZ protein (UniProt/SwissProt Accession No. Q37953) and the first 20 aminoacids of E.coli purine nucleoside phosphorylase [14]

- the tetracycline resistance gene and the pUC18 origin of replication

- a multicloning site.

pUC18 derived vectors containing the inducible lac promoter when transformed into JM109 E.coli strains constitutively express the encoded genes without any addition of inducing agents such as IPTG or lactose [14, 17].

The sequence coding for Met-MTGase ${ }_{1-332}$ was amplified by PCR from PL444 using the sense primer 5' GTTTAAACGTATGGACAGCGATGACCG 3' (with the PmeI site and the Met-MTGase start codon underlined) and the antisense primer $5^{\prime}$ TCTAGAGTCATT ATGGCCAGCCTTGTTTAAC 3' (with the XbaI site and the complementary sequence of a double stop codon underlined). 


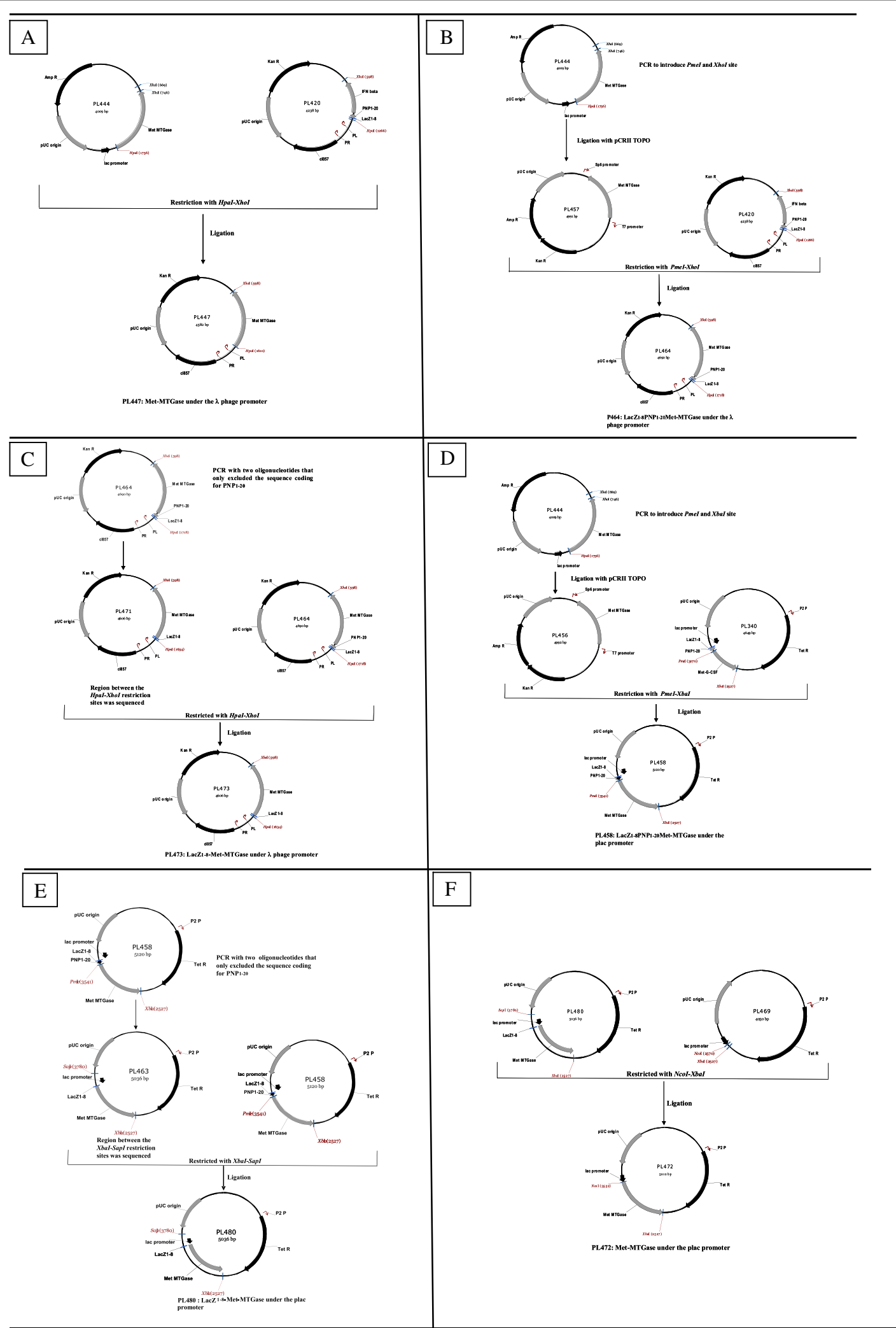

Fig. 1 Construction and structure of MTG expression plasmids. Thermoinducible plasmids, panel: a, b and $\mathbf{c}$ (PL447, PL464 and PL473) and constitutive plasmids, panel: $\mathbf{d}$, e and $\mathbf{f}$ (PL458, PL480 and PL472). The restriction enzyme sites used for construction of the plasmids are indicated. Additional details are described in Methods 
The amplified fragment was cloned in pCRII TOPO (TA Cloning kit, Cat $\mathrm{n}^{\circ} \mathrm{K} 2020-20$, Invitrogen) obtaining PL456 and later restricted by PmeI-XbaI and cloned in the same restriction sites of PL340 downstream of sequence coding for $\mathrm{LacZ}_{1-} 8 \mathrm{PNP}_{1-20}$ to obtain the vector PL458 for the constitutive expression of the chimeric protein $\mathrm{LacZ}_{1-8} \mathrm{PNP}_{1-20}$ Met-MTGase (Fig. 1, panel d).

The vector for expressing $\mathrm{LacZ}_{1-8}$ Met-MTGase under the lac promoter was constructed using an intermediate vector called PL463.

The vector was prepared by PCR amplification of PL458 with two oligonucleotides that only excluded the sequence coding for $\mathrm{PNP}_{1-20}$ using the sense primer $5^{\prime}$ ATGGAC AGCGATGACCGCGTG 3' (with Met-MTGase start codon underlined) and the antisense primer 5' GGAAG AATTCGTAATCATGGTCATAGCTG 3' (where the first underlined codon is the complementary codon for the last aminoacid of $\mathrm{LacZ}_{1-8}$ fragment). Since plasmid PL463 had been amplificated by PCR, the region between the XbaI-SapI restriction sites was sequenced and then transferred into PL458 restricted with the same enzymes to obtain the vector for the constitutive expression of chimeric $\mathrm{LacZ}_{1-8}$ Met-MTGase denominated PL480 (Fig. 1, panel e).

In order to obtain a plasmid with lac promoter that expresses Met-MTGase was used a plasmid called PL469 previously prepared in our laboratory. PL469 contains the tetracycline resistance gene, the pUC18 origin of replication and the $\mathrm{LacZ}_{1-8}$ between $\mathrm{NcoI}$ XbaI sites. So PL480 was restricted with NcoI-XbaI and the fragment was inserted into PL469 restricted with the same enzymes to obtain the vector for the constitutive expression of Met-MTGase denominated PL472 (Fig. 1, panel f).

\section{Cloning and expression of different Met-MTGase and chimeric Met-MTGase coding vectors}

Competent Escherichia coli K12, JM109 cell strains were transformed by electroporation with several purified plasmids as described in Table 1.

Transformed cells were streaked onto agar plates prepared in $\mathrm{LS}_{10}$ medium $5 \mathrm{~g} / \mathrm{l}$ yeast extract, $10 \mathrm{~g} / \mathrm{l}$ soytone, $10 \mathrm{~g} / \mathrm{l}$ sodium chloride containing $12.5 \mathrm{mg} / \mathrm{l}$ tetracycline and incubated in a static incubator (B 12, Heraeus Instruments) overnight at $37{ }^{\circ} \mathrm{C}$. Four isolated colonies of each transformed strain were selected from the agar plates and used to inoculate $10 \mathrm{ml} \mathrm{LS}{ }_{10}$ culture medium in a $100 \mathrm{ml}$ shake flasks, which were incubated at $220 \mathrm{rpm}$ and $37 \mathrm{C}$ overnight in an orbital shaker (Innova 4330, New Brunswick). About $6 \mathrm{ml}$ of each of the incubated cell suspensions were adjusted to a final concentration of $16 \% \mathrm{v} / \mathrm{v}$ glycerol, distributed in four cryo-vials and stored frozen at $-80{ }^{\circ} \mathrm{C}$.

About $100 \mu \mathrm{l}$ were taken from each of four cryo-vials of the six recombinant strains and used to inoculate $10 \mathrm{ml}$ of a rich, complex culture medium $(18 \mathrm{~g} / \mathrm{l}$ yeast extract, $10 \mathrm{~g} / \mathrm{l}$ soy peptone, $10 \mathrm{~g} / \mathrm{l}$ glycerol, $3.2 \mathrm{~g} / \mathrm{l} \mathrm{K}_{2} \mathrm{HPO}_{4}, 0.6 \mathrm{~g} / \mathrm{l}$ $\mathrm{KH}_{2} \mathrm{PO}_{4}, 1 \mathrm{~g} / \mathrm{l} \mathrm{MgSO}_{4} .7 \mathrm{H}_{2} \mathrm{O}$ and $0.03 \mathrm{~g} / \mathrm{l}$ kanamycin) in $100 \mathrm{ml}$ shake flasks incubated overnight using an orbital shaker at $220 \mathrm{rpm}$ and $37^{\circ} \mathrm{C}$.

$1.5 \mathrm{ml}$ samples of each overnight cultures of constitutively expressed recombinant Met-MTGase (NP667, NP650 and NP676 strains) were pelleted by centrifugation at $+4{ }^{\circ} \mathrm{C}$, washed with $1.6 \mathrm{ml}$ of $20 \mathrm{mM}$ Tris- $\mathrm{HCl}-1 \mathrm{mM}$ EDTA- - H 7 buffer, suspended in phosphate buffer saline to $\mathrm{OD}_{600 \mathrm{~nm}}$ value of about 100 and analysed by reducing SDS-PAGE with Coomassie blue staining.

Overnight cultures of recombinant Met-MTGase expressed under the $\lambda$ phage promoter (NP637, NP656

Table 1 List of plasmids and related strains, engineered for different MTGase expression forms in Escherichia coli, fermented in shake flask for protein expression detection

\begin{tabular}{|c|c|c|c|c|c|}
\hline Plasmid & Type & Cell strain & Promoter & Cloned gene & Antibiotic resistance \\
\hline PL444 (Sloning) & Starting & NP647 & Lac promoter & Met-MTGase ${ }_{1-332}$ & Amp \\
\hline PL447 & Expression & NP637 & $\lambda$-phage & Met-MTGase $_{1-322}$ & Kan \\
\hline PL456 & Intermediate & NP648 & T7-SP6 Promoter & Met-MTGase $_{1-332}$ & Amp-Kan \\
\hline PL457 & Intermediate & NP649 & T7-SP6 Promoter & Met-MTGase $_{1-332}$ & Amp-Kan \\
\hline PL458 & Expression & NP650 & Lac promoter & LacZ $_{1-8}$ PNP $_{1-20}$ Met-MTGase $_{1-332}$ & Tet \\
\hline PL463 & Intermediate & NP655 & Lac promoter & LacZ $_{1-8}$ Met_MTGase ${ }_{1-332}$ & Tet \\
\hline PL464 & Expression & NP656 & Phage $\lambda$ & LacZ $_{1-8}$ PNP $_{1-20}$ Met-MTGase $1-332$ & Kan \\
\hline PL469 & Expression & NP663 & Lac promoter & $\operatorname{LacZ}_{1-8}$ & Tet \\
\hline PL471 & Intermediate & NP666 & Phage $\lambda$ & LacZ $_{1-8}$ Met-MTGase ${ }_{1-332}$ & Kan \\
\hline PL472 & Expression & NP667 & Lac promoter & Met-MTGase 1-332 & Tet \\
\hline PL473 & Expression & NP668 & Phage $\lambda$ & LacZ $_{1-8}$ Met-MTGase ${ }_{1-332}$ & Kan \\
\hline PL480 & Expression & NP676 & Lac promoter & LacZ $_{1-8}$ Met-MTGase ${ }_{1-332}$ & Tet \\
\hline
\end{tabular}


and NP668) were diluted with $50 \mathrm{ml}$ of rich medium and incubated in $250 \mathrm{ml}$ shake flasks at $37{ }^{\circ} \mathrm{C}$ for about $2 \mathrm{~h}$ up to an $\mathrm{OD}_{600}$ value of $0.5 \pm 0.1$. Afterwards the cultures were then incubated for a further $4 \mathrm{~h}$ in orbital shakers at $42^{\circ} \mathrm{C}$.

$1.5 \mathrm{ml}$ taken from of each cell suspensions were prepared and analysed by reducing SDS-PAGE as described.

Since no significant difference in terms of cell growth and recombinant protein expression was observed among the four clones examined, one from each recombinant strain was selected at random for Molecular Biology cell banks to be used for large scale fermentations.

\section{Large scale preparation of MTGase fusion proteins}

The production of the MTGase fusion proteins has been performed using 10-litre scale stirred tank bioreactors (Biostat C, B. Braun). The compositions of the culture media employed were originally tested and verified for the production of other recombinant fusion proteins manufactured using the same cell host. Starting from a vial of the respective Molecular Biology cell banks, the process consisted of inoculum preparation in shake flask followed by a 10-litre scale batch or fed-batch production step.

Pre-inoculum was made starting from one vial of the Molecular Biology cell bank in culture medium FMYb, an animal free derived media composed by a pre defined solution of yeast extract, glycerol, vitamins and minerals with apposite antibiotic and then inoculated in 10 litres of FMYb culture medium for batch fermentation.

Furthermore, FM1 medium, a solution of yeast extract, glycerol, soy peptone, minerals and vitamins, was used in the same conditions for feed-batch and batch fermentation in order to investigate the best condition of expression.

\section{Bach and Fed-batch process conditions}

One vial of the Molecular Biology cell bank was inoculated in $500 \mathrm{ml} /$ flask of FMY and FM1 medium and cultivated $37{ }^{\circ} \mathrm{C}$ at $220 \mathrm{rpm}$ in an orbital shaker (Innova 4300, New Brunswick). Afterwards $100 \mathrm{ml}$ of pre-inoculum was inoculated in 10 litres culture medium: $(1 \% \mathrm{v} / \mathrm{v})$ for FMY or $(5 \% \mathrm{v} / \mathrm{v})$ for FM1.

Cultivation followed for $5 \mathrm{~h}$ at $37{ }^{\circ} \mathrm{C}$ with air flow $1 \mathrm{v} / \mathrm{v} / \mathrm{min}, \mathrm{pH}$ was controlled to $7.0 \pm 0.1$ using $12.5 \%$ $\mathrm{v} / \mathrm{v} \mathrm{NH}_{4} \mathrm{OH}$ and $20 \% \mathrm{v} / \mathrm{v} \mathrm{H}_{3} \mathrm{PO}_{4}$. The $\mathrm{pO}_{2}$ saturation was $20 \%$ controlled by stirring rate at range of 300$1300 \mathrm{rpm}$ for FMY medium and 300-1500 rpm for FM1, with a mix of pure oxygen:air at 3:20 supplied upon reaching highest stirring rate. Minimum stirring speed was settled at $300 \mathrm{rpm}$ for both media, direct air sparging was provided using ring sparger with holes on upper side, agitation using 3 separate flat-bladed ( 6 blades) Ruston impellers. Finally, foaming was controlled by antifoam addition (Antifoam 204, mixture of organic polyether dispersions).
On-line data acquisition included $\mathrm{pH}$, stirring rate, $\mathrm{pO}_{2}$, temperature and air flow rate, off-line analyses included measuring the $\mathrm{OD}_{600}$ and the $\mathrm{pH}$ during fermentation.

For fed-batch condition 8 litres of sterile culture media FM1 was prepared in bioreactor (Biostat C). In correspondence with sharp $\mathrm{pO}_{2}$ increase, indicating slower growth rate, the feed profile was 2 litres exponential feeding, 8-hour duplication time, 5 replications with air flow $1 \mathrm{v} / \mathrm{v} / \mathrm{min}$. Foaming and $\mathrm{pO}_{2}$ was controlled as reported for batch fermentation.

\section{Purification methods}

Upon completing fermentation, the cell broths were harvested and centrifuged (equivalent: 9.000 RCF; $15 \mathrm{~min} ;+4{ }^{\circ} \mathrm{C}$ ) to obtain concentrated cell paste, which was then stored frozen at $-20{ }^{\circ} \mathrm{C}$ until required.

The LacZ ${ }_{1-8}$ Met-MTGase fusion proteins, expressed in the form of cytoplasmic inclusion bodies, were recovered by suspending the cell paste $(10 \% \mathrm{w} / \mathrm{v})$ in $50 \mathrm{mM}$ sodium phosphate buffer, pH 7.4 containing $100 \mathrm{~m} \mathrm{M} \mathrm{NaCl}$, $5 \mathrm{mM}$ EDTA and $0.1 \% \mathrm{v} / \mathrm{v}$ Triton X100 at $4{ }^{\circ} \mathrm{C}$ and passing, for three successive cycles, through a high-pressure homogenizer (Manton-Gaulin) operated at $650 \pm 25$ bar.

The cell homogenate (about $6 \mathrm{l}$ ) was then cooled to below $+10{ }^{\circ} \mathrm{C}$ and batch centrifuged (equivalent: 9.000 RCF; $15 \mathrm{~min} ;+4{ }^{\circ} \mathrm{C}$ ) to pellet the inclusion bodies. The inclusion bodies were then washed twice by suspension at $+4{ }^{\circ} \mathrm{C}$ in 41 of $50 \mathrm{mM}$ sodium phosphate buffer, $\mathrm{pH} 7.4$ containing $100 \mathrm{~m} \mathrm{M} \mathrm{NaCl}, 5 \mathrm{mM}$ EDTA, under agitation for 30-60 min and then collected by centrifugation.

Washed inclusion bodies were finally suspended 1:1 in $50 \mathrm{mM}$ Tris- $\mathrm{HCl}, 5 \mathrm{mM}$ EDTA, $\mathrm{pH} 8.0$ to form an homogeneous slurry in a volume of about $3-4 \%$ of initial cell broth volume, suitably aliquoted and stored frozen at $-20{ }^{\circ} \mathrm{C}$ until required.

LacZ $_{1-8}$ Met-MTGase inclusion bodies were dissolved $(10 \% \mathrm{w} / \mathrm{v})$ in the solubilisation buffer $(8 \mathrm{M}$ urea containing $50 \mathrm{mM}$ sodium acetate and $20 \mathrm{mM}$ dithiothreitol (DTT), pH 5.2) and incubated, in mild agitation, for $1 \mathrm{~h}$ at room temperature. The solubilisation buffer was added to the washed inclusion bodies preparation at a constant flow rate within about $10 \mathrm{ml} / \mathrm{min}$, to obtain a protein concentration of about $3 \mathrm{mg} / \mathrm{ml}$.

The solubilised $\mathrm{LacZ}_{1-8}$ Met-MTGase solution was then diluted 20-fold to a concentration of $0.32 \mathrm{M}$ Urea using $20 \mathrm{mM}$ sodium acetate, $\mathrm{pH}$ 5.2. After $1 \mathrm{~h}$ of incubation in mild agitation at $+4{ }^{\circ} \mathrm{C}$, the $\mathrm{pH}$ was shifted from 5.2 to 6.0 by adding $1 \mathrm{M} \mathrm{NaOH}$.

The refolded $\mathrm{LacZ}_{1-8}$ Met-MTGase protein solutions were clarified by centrifugation at $17.700 \mathrm{RCF}$ for $10 \mathrm{~min}$ and at $4^{\circ}$ to remove any precipitated material and concentrated using a $10 \mathrm{kDa}$ cut-off ultrafiltration membrane (PrepScale-1 $\mathrm{ft}^{2}$, Millipore). The solubilization and refold reagents used were then removed by dialysis against 
$50 \mathrm{mM}$ Tris acetate, $\mathrm{pH} 8.00$ and the protein concentrate was drained down so that the equipment rinsed with the dialysis buffer recover residual product.

LacZ $_{1-8}$ Met-MTGase was purified by hydrophobic interaction chromatography on Phenyl Sepharose 6 Fast Flow (high substitution) (Fig. 2). The resin was packed to a column height of $22 \mathrm{~cm}$, column diameter of $16 \mathrm{~mm}$ and the column operated at linear flow rates up to $300 \mathrm{~cm} / \mathrm{h}$. The column was equilibrated with $3.5 \mathrm{M}$ sodium chloride, $50 \mathrm{mM}$ sodium acetate at $\mathrm{pH}=5.5$ (acetic acid). The load material consisted of the dialysed sample adjusted to $3.5 \mathrm{M} \mathrm{NaCl}$, acidified to $\mathrm{pH} 5.5$ using acetic acid diluted 1:20 and filtered $0.22 \mu \mathrm{m}$. After loading, the column was washed (4 CV) using the equilibration buffer. LacZ ${ }_{1-8}$ Met-MTGase was eluted using a step elution with $0.5 \mathrm{M}$ sodium chloride $50 \mathrm{mM}$ sodium acetate, $\mathrm{pH}$ 5.5. A buffer exchange column was necessary to put the material in the right conditions for the enzyme-catalysed reaction of pegylation.

\section{Analytical methods}

Expression of MTGase and MTGase fusion proteins was monitored by staining with Coomassie Blue R-250 after
$12 \%$ SDS-PAGE analysis [18] of solubilized cells using a Bio-Rad mini-gel apparatus as well as by RP-HPLC carried out on a C4 Vydac 214TP52 column $(2.1 \times 250 \mathrm{~mm}, 5 \mu \mathrm{m}$ particle size, Grace) at $40{ }^{\circ} \mathrm{C}$ with UV detection at $215 \mathrm{~nm}$. MTGase was eluted at $0.2 \mathrm{~mL} / \mathrm{min}$ starting from the mobile phases A ( $0.1 \% \mathrm{v} / \mathrm{v}$ TFA in $\mathrm{H} 2 \mathrm{O})$ and $\mathrm{B}(0.08 \% \mathrm{v} / \mathrm{v}$ TFA in $\mathrm{CH} 3 \mathrm{CN}$ ) with the following linear gradients: from $30 \%$ to $59 \%$ of phase B in 13 min and from $59 \%$ to $85 \%$ of phase B in 7 min.

Transglutaminase activity was measured by a described colorimetric method based on hydroxamate formation [19]. Briefly, $0.2 \mathrm{~mL}$ of $200 \mathrm{mM}$ Tris-buffer pH 6.0 containing $36 \mathrm{mM}$ carbobenzoxy-glutaminyl-glycine, $100 \mathrm{mM}$ hydroxylamine and $10 \mathrm{mM}$ reduced glutathione were incubated for $10 \mathrm{~min}$ at $37^{\circ} \mathrm{C}$ with $30 \mu \mathrm{L}$ of test sample. The enzymatic reaction was stopped by adding $0.5 \mathrm{~mL}$ of $12 \%$ trichloroacetic acid. After that, $0.5 \mathrm{~mL}$ of $5 \%$ ferric chloride exahydrate solutions were added and the resulting red color was measured at $525 \mathrm{~nm}$. A calibration curve was prepared using commercially available L-glutamic acid $\gamma$-monohydroxamate. One unit of MTGase activity is defined as the amount of enzyme that catalyzes the formation of $1.0 \mu$ mole of hydroxamate/min at the above

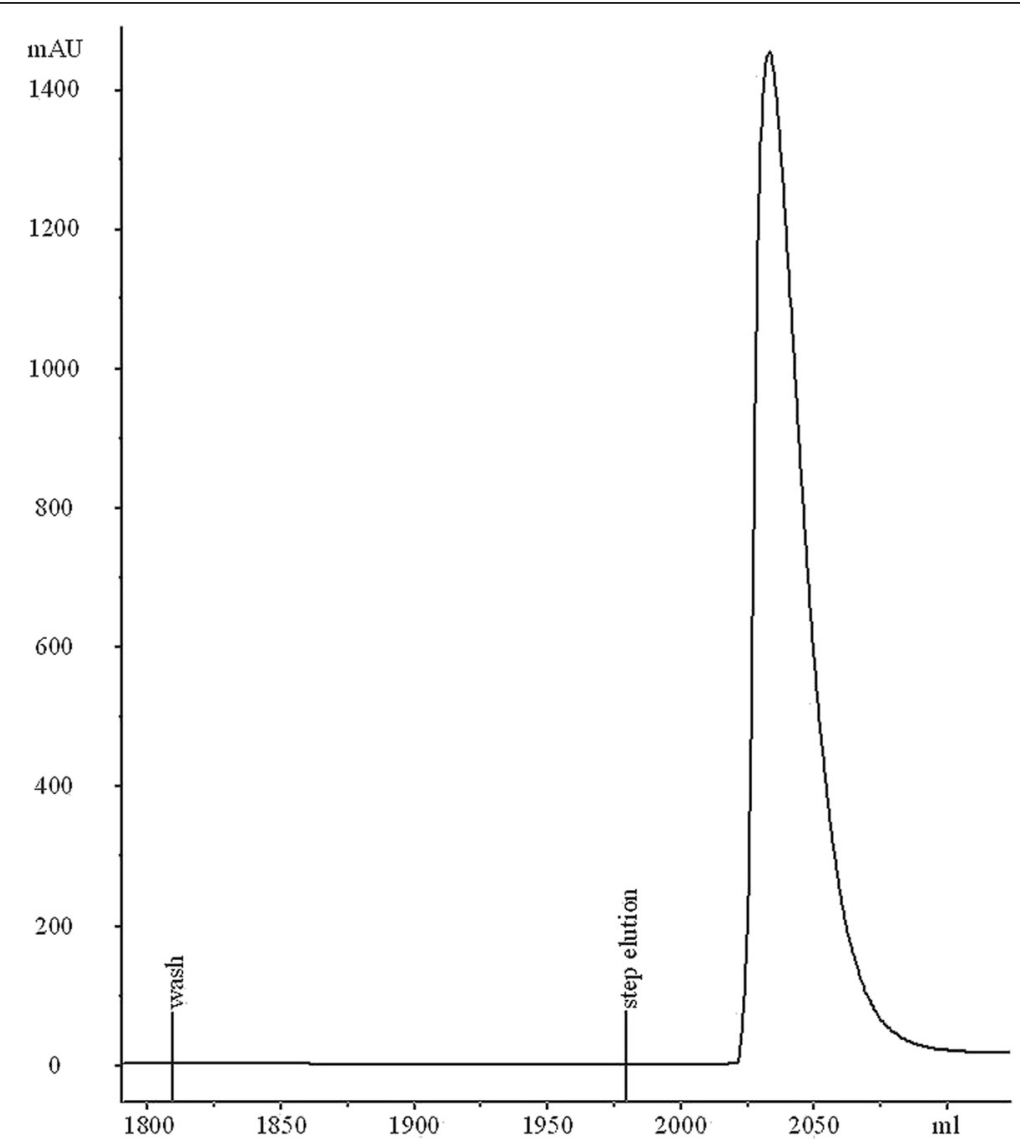

Fig. 2 Hydrophobic interaction chromatography of LacZ ${ }_{1-8}$ Met-MTGase on phenyl Sepharose with a step elution of 0,5 M sodium chloride, 50 mM sodium acetate, $\mathrm{pH} 5.5$ buffer, at room temperature 
reported conditions. Specific activity is expressed as MTGase units/mg of protein.

Purity and concentration of MTGase were determined by HPLC analysis. SE-HPLC was carried out using a TSKgel SuperSW3000column $(4.6 \times 300 \mathrm{~mm}, 4 \mu \mathrm{m}$ particle size, Tosoh Bioscience). The column was thermostated at $25{ }^{\circ} \mathrm{C}$ and eluted with $0.05 \mathrm{M} \mathrm{NaH}_{2} \mathrm{PO}_{4}, 0.4 \mathrm{M} \mathrm{NaClO}_{4}, \mathrm{pH}$ 6.0, at a flow rate of $0.35 \mathrm{~mL} / \mathrm{min}$. The UV detector was set at $215 \mathrm{~nm}$. RP-HPLC was performed on a C4 Vydac 214TP54 column $(4.6 \times 250 \mathrm{~mm}, 5 \mu \mathrm{m}$ particle size, Grace), thermostated at $55{ }^{\circ} \mathrm{C}$ and equilibrated with $75 \%(\mathrm{v} / \mathrm{v})$ buffer A (0.1\% TFA v/v in $\left.\mathrm{H}_{2} \mathrm{O}\right)$ and $25 \%(\mathrm{v} / \mathrm{v})$ buffer B $\left(0.08 \%\right.$ TFA v/v in $\left.\mathrm{CH}_{3} \mathrm{CN}\right)$. The enzyme was eluted at a flow rate of $0.8 \mathrm{~mL} / \mathrm{min}$ with a linear gradient from $25 \%$ to $45 \%$ of buffer B in 23 min, recording the absorbance at $215 \mathrm{~nm}$. Quantization was carried out by the external standard method, using a standard bovine serum albumin (BSA) solution as reference solution.

We also verified the functionality of the obtained recombinant transglutaminase by the process for sitespecific pegylation of Met-GCSF developed by Bio-Ker [20]. Briefly Met-GCSF was submitted to covalent conjugation at glutamine 135 residue with a $20 \mathrm{kDa}$ amine derivative of polyethylene glycol $\left(\mathrm{PEG}_{20 \mathrm{kDa}}-\mathrm{NH}_{2}\right)$ via enzyme-catalysed reaction using the purified Ajinomoto "wild type" microbial transglutaminase in comparison with the purified $\mathrm{LacZ}_{1-8}$ Met-MTGase from NP668/1. The experimental conditions where PEG/Met-GCSF ratio 10:1, [Met-GCSF] $]_{\text {final }} 2 \mathrm{mg} / \mathrm{ml}$, [TGase] $]_{\text {final }} 0.25 \mathrm{U} / \mathrm{ml}$ solution, $4{ }^{\circ} \mathrm{C}$, buffer $\mathrm{KH}_{2} \mathrm{PO} 420 \mathrm{mM}$ and $\mathrm{pH}$ 8,1.

\section{Results and discussion}

Purity of $\mathrm{LacZ}_{1-8}$ Met-MTGase has been evaluated by electrophoresis and HPLC analysis. A single protein band was observed on SDS-PAGE gels under both reducing and non reducing conditions at the expected molecular weight (Fig. 3). The size-exclusion and reverse-phase chromatograms showed a single symmetric peak corresponding to $99.6 \%$ and $88.8 \%$ protein purity, respectively, under native conditions (Fig. 4). The enzyme purity was confirmed by TGase activity assay which gave a specific activity of $24 \mathrm{U} / \mathrm{mg}$.

\section{Expression systems and assessment}

Four different recombinant cell strains, expressing a Met-MTGase fusion protein with two different N-terminal fusion partners in two separate expression systems, have been assessed. Specifically, the long $\mathrm{LacZ}_{1-8} \mathrm{PNP}_{20}$ MetMTGase fusion protein was expressed in cell strains NP650/1 under constitutive lac promoter and NP656/1 under the thermoinducible phage lambda promoter.

The shorter fusion protein $\mathrm{LacZ}_{1-8}$ Met-MTGase, having just the first eight $\mathrm{N}$-terminal amino acids of beta galactosidase at the $\mathrm{N}$-terminal, was expressed in thermoinducible

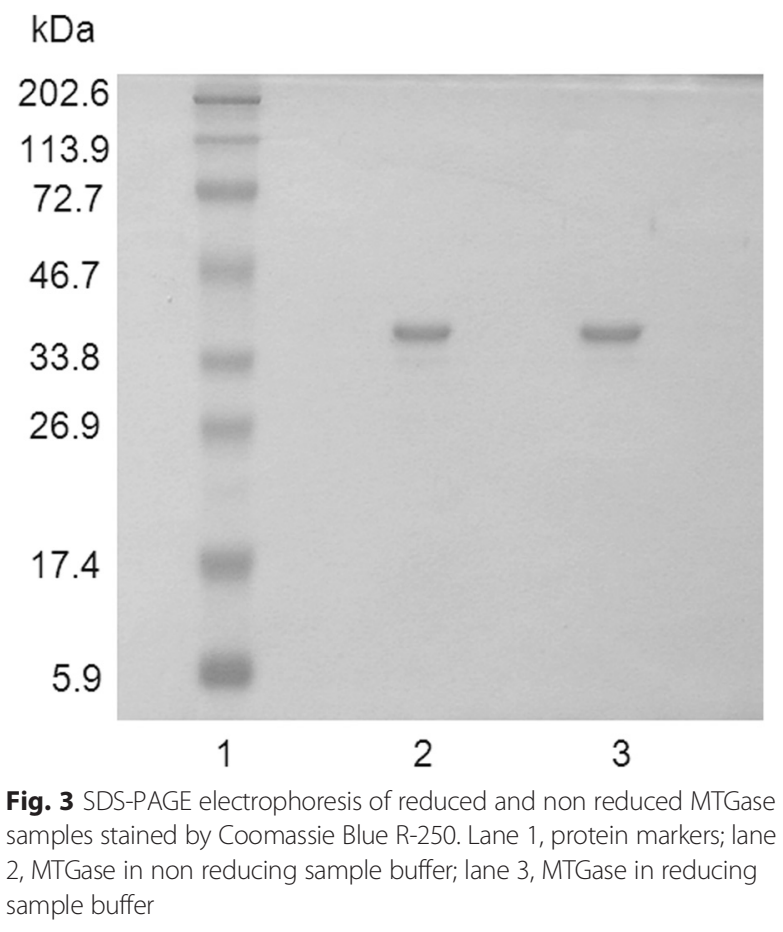

cell strain NP668/1 and constitutive cell strain NP676/1 (later replaced by NP676/2). None appreciable level of protein expression could be discerned by SDS-PAGE analysis for the strains expressing Met-MTGase without an N-terminal fusion partner (NP637/1 and NP667/1). All the others strains possessing an $\mathrm{N}$-terminal fusion partner yielded a good level of protein expression. Apart from the NP676 cell strain, expressing LacZ ${ }_{1-8}$ Met-MTGase, which was characterised by a long time of growth, the other three cell strains were incubated without problems suggesting that expression of Met-MTGase protein was not deleterious for the cell host.

\section{Fermentation studies}

As a result of preliminary experiments, a total of four different cell strains were selected to be tested using the 10-litre fermentation process, namely NP650/1, NP656/1, NP668/1 and NP676/1 (Table 2). As described below the NP676 cell strain was transformed twice (NP676/2) and also fermented.

The constitutive NP650/1 cell strain yielded a very high volumetric productivity in terms of cell broth volume of more than $6 \mathrm{~g} / \mathrm{L} \mathrm{LacZ}_{1-8} \mathrm{PNP}_{1-20}$ Met-MTGase fusion protein for a fed-batch fermentation process. Since this fed batch process typically lasted from 30 to $45 \mathrm{~h}$, depending upon the adopted feeding profile, the same cell strain was tested using a batch process shortening the production time to about $8 \mathrm{~h}$. However, despite a comparable final biomass content, a relatively low volumetric productivity of only $1.65 \mathrm{~g} / \mathrm{l}$ was obtained. These results were confirmed 
A

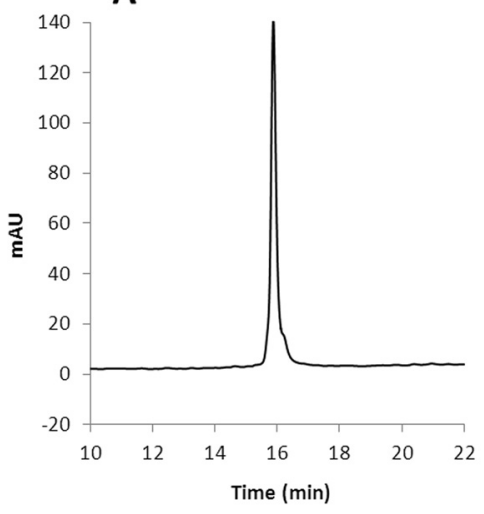

B

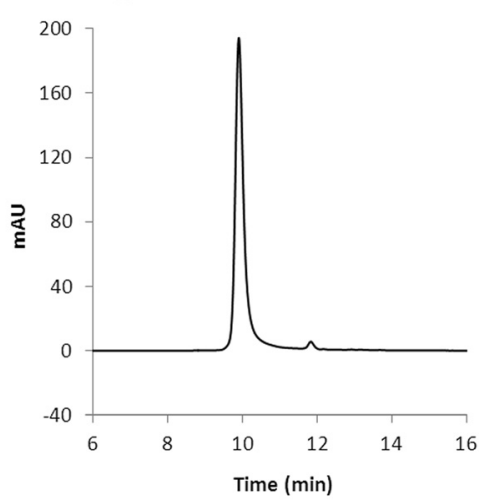

Fig. 4 Reverse-phase (a) and size-exclusion HPLC (b) analysis of purified MTGase from NP668

by repeating the processes. In any case, cytoplasmic expression of the $\mathrm{LacZ}_{1-8} \mathrm{PNP}_{1-20}$ Met-MTGase fusion protein didn't appear to have any appreciable toxic effect or to be detrimental to the growth of the host cell strain.

The same constitutive expression system was tested for Met-MTGase having the shorter N-terminal fusion partner (cell strain NP676/1) but all of four fed-batch production runs were terminated due to excessive foaming.

Considering that in other similar experiments, constitutive systems expressing long $\mathrm{LacZ}_{1-8} \mathrm{PNP}_{1-20}$ Met-MTGase fusion protein had no apparent toxic effect on the cells, we repeated the previous experiment transforming again the plasmid in a newly aliquot of competent cells obtaining a new cell bank named NP676/2. The new transformed cell strain was also characterized by slow growth, anyway two fed-batch fermentation processes have been completed, resulting in a final volumetric productivity of about $2.5 \mathrm{~g} / \mathrm{l}$ and a specific productivity, product titre in terms of grams cell wet weight, of about $36 \mathrm{mg} / \mathrm{g}$.

Five fermentation batches using the thermo-inducible NP656/1 cell strain expressing the $\mathrm{LacZ}_{1-8} \mathrm{PNP}_{20}$ MetMTGase fusion protein were performed, the fermenter temperature was shifted to $42{ }^{\circ} \mathrm{C}$ at an $\mathrm{OD}_{600}$ value of 13 after $3.5 \mathrm{~h}$ incubation and a final product yield of $3 \mathrm{~g} / \mathrm{l}$ was obtained. In another batch the temperature shift was performed after $5.5 \mathrm{~h}$ incubation, at an $\mathrm{OD}_{600}$ value of 36 , resulting in a lower final volumetric productivity of $1.65 \mathrm{~g} / \mathrm{l}$.

In both batches, an high level of protein expression has been obtained after only four hours post-induction and no expressed product were observed before induction. In a third batch, the temperature shift was performed after $2 \mathrm{~h}$ incubation at a very low $\mathrm{OD}_{600}$ value of 4.5 which resulted in a low final biomass content (final $\mathrm{OD}_{600}$ value of 18 ) and a lower product yield of $1.3 \mathrm{~g} / \mathrm{l}$. The highest volumetric productivity, $3.85 \mathrm{~g} / \mathrm{l}$, was obtained when the temperature shift was performed at an $\mathrm{OD}_{600}$ value of 18 , corresponding to the mid-point of the exponential growth phase.

In addition to the above described fermentations operated in a batch mode, similar five batches were run in a fed-batch mode. As result, final biomass and concentrations were comparable, but high expression yield of up to $4 \mathrm{~g} / \mathrm{l}$ were obtained. Considering only the fed-batch processes performed using the optimal conditions, a mean specific productivity value of about $80 \mathrm{mg} / \mathrm{g}$ was obtained for NP650/1 compared to about $100 \mathrm{mg} / \mathrm{g}$ for NP656/1.

The thermoinducible NP668/1 cell strain expressing the shorter $\mathrm{LacZ}_{1-8} \mathrm{MTGase}$ fusion protein yielded a maximum volumetric productivity of about $3 \mathrm{~g} / \mathrm{l}$.

Table 2 Fermentation of four most performing strains expressing MTGase, comparison of two expression systems

\begin{tabular}{|c|c|c|c|c|c|c|}
\hline Fusion protein & Batch \# & System & FB/batch & Final $\mathrm{OD}_{600}$ & MTGase (g/batch) & Wet mass (g) \\
\hline \multirow[t]{3}{*}{ LacZ $_{1-8}$ Met-MTGase } & NP676/C002 & Constitutive & Batch & 60 & 26,7 & 693 \\
\hline & NP676/C001 & & Fed-batch & 57 & 24,1 & 709 \\
\hline & NP668/009 & Inducible & Batch & 54 & 25,0 & 540 \\
\hline \multirow[t]{4}{*}{ LacZ $_{1-8} \mathrm{PNP}_{1-8}$ Met-MTGase } & NP650/C005 & Constitutive & Batch & 58 & 16,5 & 790 \\
\hline & NP650/C006 & & Fed-batch & 74 & 62,0 & 748 \\
\hline & NP656/C009 & Inducible & Batch & 46 & 39,2 & 335 \\
\hline & NP656/C010 & & Fed-batch & 56 & 42,7 & 490 \\
\hline
\end{tabular}


Table 3 List of NP668/1 fermentation batches to investigate the optimal point of temperature shift

\begin{tabular}{|c|c|c|c|c|}
\hline Batch \# & $\mathrm{OD}_{600}$ & $\begin{array}{l}\text { LacZ }_{1-8} \text { Met- } \\
\text { MTGase (mg/l) }\end{array}$ & Wet mass (g) & $\begin{array}{l}\text { LacZ }_{1-8} \text { Met- } \\
\text { MTGase (mg/g) }\end{array}$ \\
\hline NP668/C001 & 58 & 1117 & 744 & 15,0 \\
\hline NP668/C002 & 64 & 2191 & 604 & 36,3 \\
\hline NP668/C003 & 56 & 3085 & 493 & 62,6 \\
\hline NP668/C004 & 51 & 1548 & 646 & 24,0 \\
\hline NP668/C005 & 58 & 2907 & 590 & 49,3 \\
\hline NP668/C006 & 60 & 2376 & 580 & 41,0 \\
\hline NP668/C007 & 58 & 2761 & 560 & 49,3 \\
\hline NP668/C008 & 42 & 2109 & 384 & 54,9 \\
\hline NP668/C009 & 54 & 2500 & 540 & 46,3 \\
\hline NP668/C010 & 53 & 2520 & 538 & 46,7 \\
\hline NP668/C013 & 60 & 2633 & 591 & 44,6 \\
\hline NP668/C014 & 59 & 2196 & 564 & 38,9 \\
\hline NP668/C015 & 60 & 1939 & 572 & 33,9 \\
\hline NP668/C016 & 50 & 2157 & 575 & 37,5 \\
\hline NP668/C017 & 37 & 1377 & 522 & 26,4 \\
\hline NP668/C018 & 33 & 2415 & 497 & 48,6 \\
\hline NP668/C019 & 32 & 1677 & 571 & 29,4 \\
\hline Mean & 52 & 2206 & 563 & 40,3 \\
\hline$S d$ & 10 & 541 & 74 & 12,0 \\
\hline
\end{tabular}

This cell strain was tested according to the batch production mode only and, the optimal point for the temperature shift to $42{ }^{\circ} \mathrm{C}$ corresponded to an $\mathrm{OD}_{600}$ value of about 20 (Table 3 ) giving a mean specific productivity of $40 \mathrm{mg} / \mathrm{g}$ cell wet weight, while in the same conditions were obtained for NP656/1 a productivity of $100 \mathrm{mg} / \mathrm{g}$. Shifting the temperature at an $\mathrm{OD}_{600}$ value of 30 or more resulted in a markedly lower yield of 1.2-
Table 4 Enzymatic activity of purified MTGase, comparison among the two best performing expression systems and wild type

\begin{tabular}{lll}
\hline NP650C001 & NP668C003 & AJ021 \\
\hline LacZ $_{1-8}$ PNP $_{1-20}$ Met-MTGase & LacZ ${ }_{1-8}$ Met-MTGase & Wild type \\
$15,1 \mathrm{U} / \mathrm{mg}$ & $24 \mathrm{U} / \mathrm{mg}$ & $22 \mathrm{U} / \mathrm{mg}$ \\
\hline
\end{tabular}

$2.2 \mathrm{~g} / \mathrm{l}$, whereas a value of $2.1 \mathrm{~g} / \mathrm{l}$ was obtained at a low $\mathrm{OD}_{600}$ value of 13 .

The constitutive NP650/1 cell strain gave the highest volumetric productivity of $6.15 \mathrm{~g} / \mathrm{l}$, on the other hand, the thermoinducible cell strain NP656/1 exhibited a lower protein yield, but showed a more specific productivity in terms of $\mathrm{mg}$ of protein/cells (wet weight).

For both systems was evident that long $\mathrm{LacZ}_{1-8} \mathrm{PNP}_{1-}$ ${ }_{20}$ Met-MTGase fusion protein yielded both a higher volumetric and specific productivity, demonstrating the advantage of co-expressing the MTGase protein with the $\mathrm{PNP}_{1-20}$ peptide. It should be pointed out that this benefit is somewhat reduced if the additional mass, corresponding to about $10 \%$ of the expressed protein, of the $\mathrm{PNP}_{1-20}$ peptide itself is taken into account.

\section{Purification and quality assessment}

According to the preliminary fermentation process studies, the two most performing fusion protein systems namely short thermoinducible LacZ $_{1-8}$ Met-MTGase (NP668/1) and long constitutive $\mathrm{LacZ}_{1-8} \mathrm{PNP}_{1-20}$ Met-MTGase (NP6 $50 / 1$ ) has been chosen to compare both efficiency of expression and biochemical qualities of the product.

Proteins were extracted and purified to homogeneity and so verified as a single peak obtained in RP-HPLC. The LacZ ${ }_{1-8} \mathrm{PNP}_{1-20}$ Met-MTGase fusion protein purified from NP650/1 exhibited an activity of $15 \mathrm{U} / \mathrm{mg}$ compared to $24 \mathrm{U} / \mathrm{mg}$ for the shorter fusion protein purified from

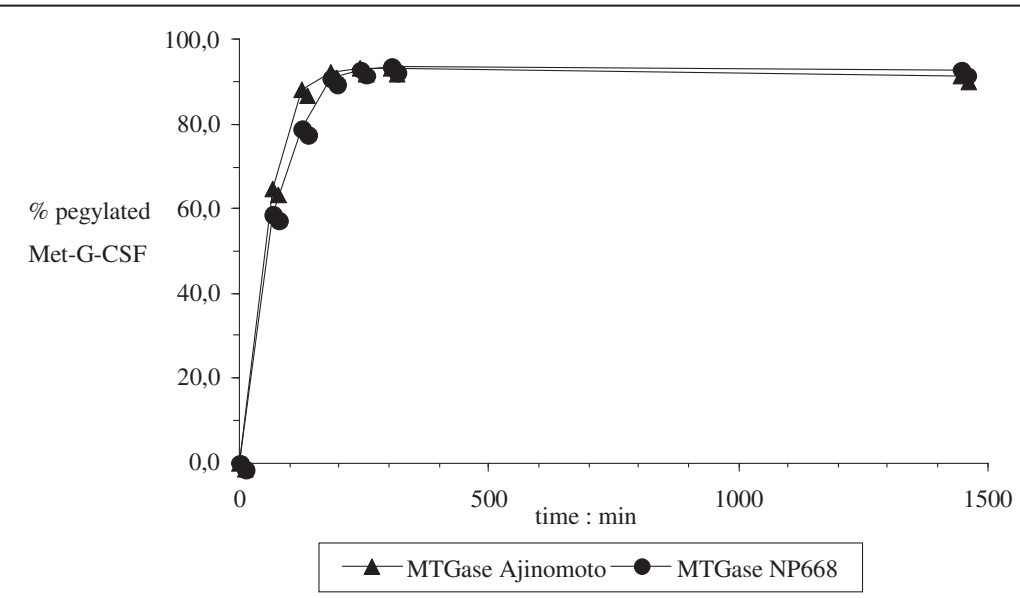

Fig. 5 Kinetic profile functionality of NP668 versus Ajinomoto MTGase by comparing the enzymatic activities in covalent conjugation of 20 kDa amine derivative of polyethylene glycol at glutamine 135 residue of Met-G-CSF 
NP668/1 cell strain (Table 4). The lower activity obtained for the $\mathrm{LacZ}_{1-8} \mathrm{PNP}_{1-20}$ Met-MTGase could be attributable to the presence of the long $\mathrm{PNP}_{1-20}$ peptide chain, therefore, despite the lower protein expression yield obtained, the thermoinducible cell strain NP668/1 expression has been chosen as most performing expression system.

Comparison of the functionality of the $\mathrm{LacZ}_{1-8}$ MetMTGase fusion protein (NP668/1) versus the Ajinomoto "wild type" microbial transglutaminase showed a same reaction kinetic profile for both products. In both cases the reaction reached the plateau after four hours and the reaction yields were comparable likewise the chromatographic profiles (SE-HPLC) (Fig. 5).

\section{Conclusions}

Due to the implication of MTGase in many industrial and pharmaceutical fields, the interest in finding the better expression conditions of this enzyme is broadly widespread [21].

In this work we have described a series of studies aimed to determine the better strategy to express MTGase comparing constitutive versus thermoinducible expression systems rather than expressing the protein by fusion protein or wild type. Moreover a comparison between two fusion partner $\left(\mathrm{LacZ}_{1-8} \mathrm{PNP}_{1-20}\right.$ and $\left.\mathrm{LacZ}_{1-8}\right)$ has been done. We showed that the expression of a MTGase fusion protein is advantageous in terms of fermentation yield and that the use of the short LacZ $\mathrm{Z}_{1-8}$ Met-MTGase fusion protein improves the enzymatic activity of the product obtaining an activity value comparable to that of the "wild type" transglutamiase (Table 4).

Thereby, the importance to have a reliable protein activity expression combined with a fast and robust method of purification led to the choice of NP668/1 as reference strain to produce Met-MTGase.

\section{Competing interests}

Bioker srl, is a biotech company located in the Scientific and Technological Park of Sardinia (Italy) fully owned by Multimedica Holding. GS is a IRCCS Multimedica employee; GT is CEO of Bioker srl while BS, DC, MB, SS and RS are Bioker's employees. GSJ is professor at University of Parma, Italy.

\section{Authors' contributions}

BS was responsible of study development and manuscript writing. R.S. was responsible of the research project. D.C. and G.T. were involved in experimental design and manuscript writing. G.S. and G.S.J. were involved in scientific advisory and manuscript drafting. SS was responsible for analytical studies whereas MB for purification process. All authors read and approved the final manuscript.

\section{Acknowledgement}

We acknowledge the Scientific and Technological Park of Sardinia that financed the article-processing charge but had no role in study design, preparation of the manuscript or decision to publish it.

\section{Author details}

${ }^{1}$ Bio-Ker S.r.l., Sardinia Scientific and Technological Park, Building 3, 09010 Pula, Cagliari, Italy. ${ }^{2}$ IRCCS MultiMedica, Milan, Italy. ${ }^{3}$ Department of Biomedical, Biotechnological and Traslational Science (S.Bi.Bi.T.), University of Parma, Via Volturno 39, 43121 Parma, Italy.

Received: 17 April 2015 Accepted: 2 September 2015

Published online: 15 September 2015

\section{References}

1. Yokoyama K, Nio N, Kikuchi Y. Properties and applications of microbial transglutaminases. Appl Microbiol Biotechnol. 2004;64:447-54

2. Bungay Peter J, Robin Owen A, lan C, Griffin M. A role for transglutaminase in glucose-stimulated insulin release from the pancreatic - cell. Biochem J. 1986;235:269-78

3. Sane DC, Kontos $\mathrm{U}$, Greenberg CS. Roles of transglutaminases in cardiac and vascular diseases. Front Biosci. 2009:12:2530-45.

4. Griffin M, Casadio R, Bergamini CM. Transglutaminase. Nature's biological glue. Biochem J. 2002;368:377-96.

5. Fontana A, Spolaore B, Mero A, Veronese FM. Site-specific modification and PEGylation of pharmaceutical proteins mediated by transglutaminase. Adv Drug Deliv Rev. 2008;60:13-28.

6. Kieliszek M, Misiewicz A. Microbial transglutaminase and its application in the food industry. A review. Folia Microbiol. 2014;59:241-50

7. Kawajiri H, Ide H, Motoki M, Shimonishi Y. Priamry structure of microbial transglutaminase from Streptoverticillium sp. Strain s-8112. J Biol Chem. 1993;268:11565-72.

8. Zotzel J, Keller P, Fuchsbauer HL. Transglutaminase from Streptomyces mobaraensis is activated by an endogenous metalloprotease. Eur J Biochem. 2003;270:3214-22.

9. Zotzel J, Pasternack R, Pelzer C, Ziegert D, Mainusch M, Fuchsbauer HL. Activated transglutaminase from Streptomyces mobaraensis is processed by a tripeptidyl aminopeptidase in the final step. Eur J Biochem. 2003;270:4149-55

10. Ando H, Adachi M, Umeda K, Matsuura A, Nonaka M, Uchio R, et al. Purification and characteristics of a novel transglutaminase derived from microorganisms. Agric Biol Chem. 1989;53:2613-7.

11. Washizu K, Ando K, Koikeda S, Hirose S, Matsuura A, Takagi H, et al. Molecular cloning of the gene for microbial transglutaminase from Streptoverticillium and its expression in Streptomyces lividans. Biosci Biotechnol Biochem. 1994;58:82-7.

12. Fu R, Chen J, Li Y. Heterologous leaky production of transglutaminase in Lactococcus lactis significantly enhances the growth performance of the host. Appl Environ Microbiol. 2005;71:8911-9.

13. Yokoyama K, Nakamura N, Saguaro K, Kubota K. Overproduction of microbial transglutaminase in Escherichia coli, in vitro refolding, and characterization of the refolded form. Biosci Biotechnol Biochem. 2000:64:1263-70.

14. Pozzuolo S, Breme U, Salis B, Taylor G, Tonon G, Orsini G. Efficient bacterial expression of fusion proteins and their selective processing by a recombinant Kex-1 protease. Protein Express Purif. 2008;59:334-41

15. Sambrook J, Russell DW, editors. Molecular Cloning.A Laboratory Manual, 3rd ed. N.Y: Cold Spring Harbor Laboratory Press; 2001.

16. Elvin CM, Thompson PR, Argall ME, Hendry P, Stamford NP, Lilley PE. Modified bacteriophage lambda promoter vectors for overproduction of proteins in Escherichia coli. Gene. 1990:87:123-6.

17. Glascock CB, Weickert MJ. Using chromosomal lad ${ }^{\mathrm{Q} 1}$ to control expression of genes on high copy number plasmids in Escherichia coli. Gene. 1998;223:221-31.

18. Laemli UK. Cleavage of structural proteins during the assembly of the head of bacteriophage T4. Nature. 1970;227(5259):680-5.15.

19. Folk JE, Cole PW. Transglutaminase: mechanistic features of the active site as determined by kinetic and inhibitor studies. Biochim Biophys Acta. $1966 ; 122: 244-64$

20. Scaramuzza S, Tonon G, Olianas A, Messana I, Schrepfer R, Orsini G, Caliceti P. A new site-specific monoPEGylated filgrastim derivative prepared by enzymatic conjugation: Production and physiochemical characterization. Journal of Controlled Release. 2012;164(3):355-63.

21. Liu S, Zhang D, Wang M, Cui W, Chen K, Du G, et al. The order of expression is a key factor in the production of active transglutaminase in Escherichia coli by coexpression with its pro-peptide. Microb Cell Fact. 2011;10:112 